\title{
DNA barcoding of Scandinavian birds reveals divergent lineages in trans-Atlantic species
}

\author{
Arild Johnsen - Eirik Rindal • Per G. P. Ericson - Dario Zuccon • \\ Kevin C. R. Kerr $\cdot$ Mark Y. Stoeckle $\cdot$ Jan T. Lifjeld
}

Received: 25 May 2009/Revised: 29 October 2009/Accepted: 21 December 2009/Published online: 10 January 2010

(C) The Author(s) 2010. This article is published with open access at Springerlink.com

\begin{abstract}
Birds are a taxonomically well-described group of animals, yet DNA barcoding, i.e., the molecular characterization of species using a standardized genetic marker, has revealed unexpected patterns of genetic divergences among North American birds. We performed a comprehensive COI (cytochrome $c$ oxidase subunit I) barcode survey of 296 species of Scandinavian birds, and compared genetic divergences among 78 trans-Atlantic species whose breeding ranges include both Scandinavia and North America. Ninety-four percent of the Scandinavian species showed unique barcode clusters; the remaining $6 \%$ had overlapping barcodes with one or more congeneric species,
\end{abstract}

Communicated by M. Wink.

Electronic supplementary material The online version of this article (doi:10.1007/s10336-009-0490-3) contains supplementary material, which is available to authorized users.

A. Johnsen $(\varangle) \cdot$ E. Rindal $~$ J. T. Lifjeld

National Centre for Biosystematics, Natural History Museum, University of Oslo, P.O. Box 1172 Blindern, 0318 Oslo, Norway

e-mail: arild.johnsen@nhm.uio.no

P. G. P. Ericson

Department of Vertebrate Zoology, Swedish Museum of Natural

History, P.O. Box 50007, 10405 Stockholm, Sweden

D. Zuccon

Molecular Systematics Laboratory, Swedish Museum of Natural History, P.O. Box 50007, 10405 Stockholm, Sweden

K. C. R. Kerr

Department of Integrative Biology, Biodiversity

Institute of Ontario, University of Guelph,

Guelph, ON N1G 2W1, Canada

M. Y. Stoeckle

Program for the Human Environment,

The Rockefeller University, New York, NY 10065, USA which may reflect incomplete lineage sorting or a single gene pool. Four species showed large intra-specific divergences within Scandinavia, despite no apparent morphological differentiation or indications of reproductive isolation. These cases may reflect admixture of previously isolated lineages, and may thus warrant more comprehensive phylogeographic analyses. Nineteen $(24 \%)$ of 78 trans-Atlantic species exhibited divergent genetic clusters which correspond with regional subspecies. Three of these trans-Atlantic divergences were paraphyletic. Our study demonstrates the effectiveness of COI barcodes for identifying Scandinavian birds and highlights taxa for taxonomic review. The standardized DNA barcoding approach amplified the power of our regional studies by enabling independently obtained datasets to be merged with the established avian barcode library.

Keywords DNA barcoding - Genetic divergence . Cytochrome $c$ oxidase I - Trans-Atlantic comparison

\section{Introduction}

DNA barcoding, the molecular characterization of species using a standardized DNA region, is a potentially effective tool for identifying species across the eukaryotes of the world (Frezal and Leblois 2008). For animals, a 648-bp fragment of the mitochondrial gene cytochrome $c$ oxidase subunit I (COI) has been chosen as the standard barcoding marker due to its high interspecific variation, low intraspecific variation, and relatively universal primers for taxonomic groups at the level of orders and even classes (Hebert et al. 2003). This marker features high resolution in many of the animal groups studies so far, e.g., Neotropical bats (Clare et al. 2007), North American birds (Kerr et al. 2007), 
Australian fishes (Ward et al. 2005), and tropical Lepidoptera (Hajibabaei et al. 2006; but see Elias et al. 2007). In other groups, resolution is more moderate, e.g., Diptera (Meier et al. 2006) and marine gastropods (Meyer and Paulay 2005). Species identification through DNA barcoding has many practical utilities such as in conservation biology (Neigel et al. 2007; Ward et al. 2008a), food security control (Wong and Hanner 2008), and birdstrike identification (Dove et al. 2008). This approach depends on a good library of COI sequences being established prior to testing the species identity of an unknown sample or specimen.

In addition to the practical utility of DNA barcoding, the method provides a means of quickly screening biodiversity to identify species or species groups with unusual genetic structure, e.g., cryptic species or species with shared COI haplotypes. The potential for discovering biologically interesting patterns should be highest among the so-called microfauna, but even in more charismatic, well-studied groups like fishes and birds, DNA barcoding has revealed cases of apparent cryptic speciation and indicated the genetic uniformity of species that are classically viewed as two or more separate species (Hebert et al. 2004; Kerr et al. 2007; Ward et al. 2005, 2008). DNA barcoding can therefore have a scientific value beyond species identification, since it can provide clues to ongoing speciation processes and direct attention to species or species complexes that deserve more detailed morphological and genetic scrutiny.

Birds are among the best-studied and taxonomically well-described animal groups, which makes them good models for testing the efficacy of DNA barcoding as a species identification tool. Two publications have summarized DNA barcoding results for the North American bird fauna (Hebert et al. 2004; Kerr et al. 2007). These studies revealed a high species identification power $(94 \%$ of species resolved), and pinpointed 15 species with deep intraspecific genetic splits (termed provisional species) and 17 congeneric species pairs/complexes with little or no differentiation. Two recent studies have focused on the ability of COI barcoding to distinguish between closely related, and potentially hybridizing, sister bird species (Aliabadian et al. 2009; Tavares and Baker 2008). While Tavares and Baker (2008) found $100 \%$ resolution of COI barcoding in a sample of 60 sister species pairs based on neighbor-joining tree clustering and diagnostic fixed substitutions, Aliabadian et al. (2009) found that a high percentage $(42 \%)$ of 36 Holarctic allopatric sister species pairs could not be distinguished based on the suggested threshold genetic distance for bird species at 10 times the average intraspecific distance (Hebert et al. 2004). Delimiting species based on a threshold of sequence difference is controversial (Meyer and Paulay 2005; Moritz and Cicero 2004) and may not be applicable to closely related species (Moritz and Cicero 2004; Tavares and Baker 2008).

A number of bird species inhabit both the Palearctic and the Nearctic region. Typically, such species are divided into one or more different subspecies on each continent, based primarily on morphology (del Hoyo et al. 19922008). Recent studies of genetic divergence in a few Holarctic species have found relatively high levels of divergence between Palearctic and Nearctic populations (e.g., Drovetski et al. 2004; Koopman et al. 2005; Zink et al. 2006). To date, no comprehensive study of the genetic divergence between populations on each side of the Atlantic Ocean has been performed. Given the presumably long history of separation and lack of current gene flow for many species, the potential for deep trans-Atlantic splits should be high.

The aims of the present study are twofold. First, we wanted to test the resolution power of DNA barcoding in species discrimination in a data set of 296 Scandinavian bird species. Second, we wanted to assess the degrees of trans-Atlantic sequence divergence for 78 species breeding both in Scandinavia and in North America.

\section{Methods}

Sampling

Blood and tissue samples originated from the tissue collections of the Swedish Museum of Natural History in Stockholm, the Natural History Museum, University of Oslo, Tromsø University Museum, Agder Museum of Natural History, Helgeland Museum, Bergen Museum, Ajtte-Swedish Mountain and Sami Museum, and Göteborg Natural History Museum. These were subsampled and subjected to DNA extraction using Omega blood/ tissue extraction kits (Omega) or QIAamp DNA Mini Kit (Qiagen). All samples originated from breeding or nonbreeding birds in Scandinavia (Norway, Sweden, and Denmark) and Svalbard, except five samples collected from three Holarctic species in Canada, with members of the same species collected from widely-spaced geographic localities whenever possible. The full details about these samples, including information about vouchers and e-vouchers, are available at the BOLD website (http://www. barcodinglife.com/), project "Birds of Scandinavia". Details about the North American samples used in the cross-Atlantic comparison can be found in Kerr et al. (2007), and sequences are available in BOLD (project: "Birds of North America-Phase II").

Species nomenclature follows the taxonomy of Clements (2007), which is also used by the "All Birds Barcoding Initiative" (http://www.barcodingbirds.org/). 
DNA sequencing

DNA extraction, PCR amplification, and DNA sequencing of the COI gene was performed at the Swedish Museum of Natural History in Stockholm and the Natural History Museum in Oslo. In the two laboratories, several combinations of primers were utilized: standard primers Bird F1 (TTCTCCAACCACAAAGACATTGGCAC), Bird R1 (ACGTGGGAGATAATTCCAAATCCTG), Bird R2 (ACT ACATGTGAGATGATTCCGAATCCAG), and COIbirdR2 (ACGTGGGAGATAATTCCAAATCCTGG), plus newly designed CO1-ExtF (ACGCTTTAACACTCAGCCATCT TACC) and CO1-ExtR (AACCAGCATATGAGGGTTCG ATTCCT). The number of different primer pairs used in this study reflects the fact that the work was carried out in two different laboratories which happened to choose different published primer sets, plus both experienced problems with sequencing some specimens, which prompted one of us (D.Z.) to design a new set of primers located outside the standard region (CO1-ExtF and CO1-ExtR). These were used either in an initial PCR before a second PCR with standard primers, or as both PCR and sequencing primers. The reasons for our problems with obtaining COI sequences from a number of individuals are unknown, but may partly be due to primer mismatches for the standard COI primers in several taxa. A recent paper described similar problems with the standard primers and recommended newly designed primers for passerines (Lohman et al. 2008).

During the course of the analyses, we used three different DNA polymerases, DyNAzyme II (Finnzymes), AmpliTaq Gold (Applied Biosystems), and Platinum taq (Invitrogen). The standard thermal profile used in Oslo was: $94^{\circ} \mathrm{C}$ for $1 \mathrm{~min}$ ( $6 \mathrm{~min}$ for AmpliTaq Gold), 5 cycles of $94^{\circ} \mathrm{C}$ for $1 \mathrm{~min}, 45^{\circ} \mathrm{C}$ for $1.5 \mathrm{~min}, 72^{\circ} \mathrm{C}$ for $1.5 \mathrm{~min}$, followed by 30 cycles of $94^{\circ} \mathrm{C}$ for $1 \mathrm{~min}, 51^{\circ} \mathrm{C}$ for $1.5 \mathrm{~min}$, $72^{\circ} \mathrm{C}$ for $1.5 \mathrm{~min}$, and a final extension at $72^{\circ} \mathrm{C}$ for $5 \mathrm{~min}$. The standard thermal profile used in Stockholm was: (1) initial PCR, using CO1-ExtF and CO1-ExtR: $95^{\circ} \mathrm{C}$ for $5 \mathrm{~min}, 2$ cycles of $95^{\circ} \mathrm{C}$ for $30 \mathrm{~s}, 66^{\circ} \mathrm{C}$ for $30 \mathrm{~s}, 72^{\circ} \mathrm{C}$ for $50 \mathrm{~s}, 2$ cycles of $95^{\circ} \mathrm{C}$ for $30 \mathrm{~s}, 64^{\circ} \mathrm{C}$ for $30 \mathrm{~s}, 72^{\circ} \mathrm{C}$ for $50 \mathrm{~s}, 16$ cycles of $95^{\circ} \mathrm{C}$ for $30 \mathrm{~s}, 62^{\circ} \mathrm{C}$ for $30 \mathrm{~s}, 72^{\circ} \mathrm{C}$ for $50 \mathrm{~s}$, and a final extension at $72^{\circ} \mathrm{C}$ for $8 \mathrm{~min}$; and (2) second PCR, using internal primers: $95^{\circ} \mathrm{C}$ for $5 \mathrm{~min}$, 4 cycles of $95^{\circ} \mathrm{C}$ for $30 \mathrm{~s}, 64^{\circ} \mathrm{C}$ for $30 \mathrm{~s}, 72^{\circ} \mathrm{C}$ for $10 \mathrm{~s}$, 4 cycles of $95^{\circ} \mathrm{C}$ for $30 \mathrm{~s}, 62^{\circ} \mathrm{C}$ for $30 \mathrm{~s}, 72^{\circ} \mathrm{C}$ for $10 \mathrm{~s}, 22$ cycles of $95^{\circ} \mathrm{C}$ for $30 \mathrm{~s}, 60^{\circ} \mathrm{C}$ for $30 \mathrm{~s}, 72^{\circ} \mathrm{C}$ for $10 \mathrm{~s}$, and a final extension at $72^{\circ} \mathrm{C}$ for $8 \mathrm{~min}$.

Pseudogenes (numts), i.e., mtDNA fragments incorporated in the nuclear genome (Bensasson et al. 2001; Sorenson and Quinn 1998), may represent a source of error since PCR-based analyses will often amplify both the authentic mitochondrial sequence and the pseudogene. In a few cases of large intra-specific variation in COI sequences (see "Results"), we checked the mitochondrial origin of our sequences by amplifying a much longer sequence of the mitochondrial genome and thereby reducing the risk of co-amplifying any pseudogene. We used the primers L6615 and H10884 (Sorenson et al. 1999), which amplify an approximately 4,000-bp mitochondrial fragment in birds, together with the GeneAmp ${ }^{\odot}$ XL PCR kit (Applied Biosystems), following the instructions of the manufacturer. We then performed a second PCR on the product of this long PCR, using primers COI-ExtF and Bird R2, and checked whether the resulting sequences were identical to those originally obtained.

\section{Dataset}

The original Scandinavian dataset consisted of 996 specimens from 302 species. However, we failed to obtain sequences from 27 specimens of 24 species. In addition, we excluded all sequences with $>1 \%$ ambiguous nucleotides from the analyses $(n=10)$. The sequences from one specimen of Glaucidium passerinum and one specimen of Motacilla flava were excluded because they contained stop codons, suggesting that they were pseudogene sequences. The original sequences from 2 specimens of Bucephala clangula proved to be very different from sequences of 9 other specimens from the same species and 18 specimens from two other congeners (Bucephala albeola and B. islandica) in the BOLD database. These samples were repeatedly amplified and sequenced with different combinations of the aforementioned COI primers, with similar results. However, using the XL-PCR procedure, we were able to recover mitochondrial COI sequences from both specimens that grouped with the other sequences from the same species. This suggests that the original sequences came from a nuclear pseudogene, despite containing no stop codons or frame-shift mutations (Song et al. 2008).

High quality sequences were thus obtained from 957 (96\%) specimens, representing 296 species. The average number of specimens per species was 3.2 (range 1-10), with 256 species consisting of two or more specimens. The sample included $97 \%$ of the 250 species breeding in Sweden and $98 \%$ of the 258 species breeding in Norway and Svalbard.

\section{Statistical procedures}

We used the analytical tools at the BOLD website (http:// www.barcodinglife.com/) to calculate nearest neighbor distances and other summary statistics (Ratnasingham and Hebert 2007). Neighbor-joining (NJ) trees were constructed based on the Kimura 2 parameter model. Bootstrap values were calculated in Mega using 1,000 iterations. 
For a subsample containing $97.7 \%$ of the specimens in the NJ tree, a Bayesian Markov chain Monte Carlo (MCMC) analysis was performed using MrBayes version 3.1.2 (Huelsenbeck and Ronquist 2001) as implemented at the Bioportal at the University of Oslo (http://www.bioportal. uio.no/). The analysis was run with 4 chains for 20 million generations, using 9 million generations as burnin, taking samples every 1,000 generations. The substitution model was determined using Mr Modeltest Version 3.7 (Posada and Crandall 1998) based on the Akaike Information Criterion (AIC). The preferred model was the general time reversible model (GTR; four nucleotide frequency state parameters; six substitution rate parameters) with a proportion of invariable sites (I) and a gamma distribution for $(G)$.

\section{Results}

DNA barcodes of Scandinavian birds

Average intraspecific distance was $0.24 \%$ (range $0-$ $5.08 \%$ ), while the average nearest neighbour distance was $7.95 \%$ (range 0-17.05\%) (Fig. 1). A total of 277 species

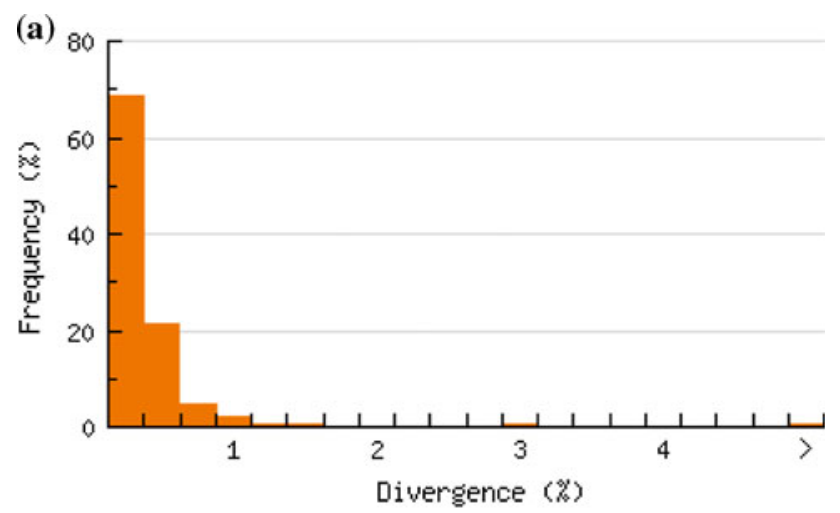

(b)

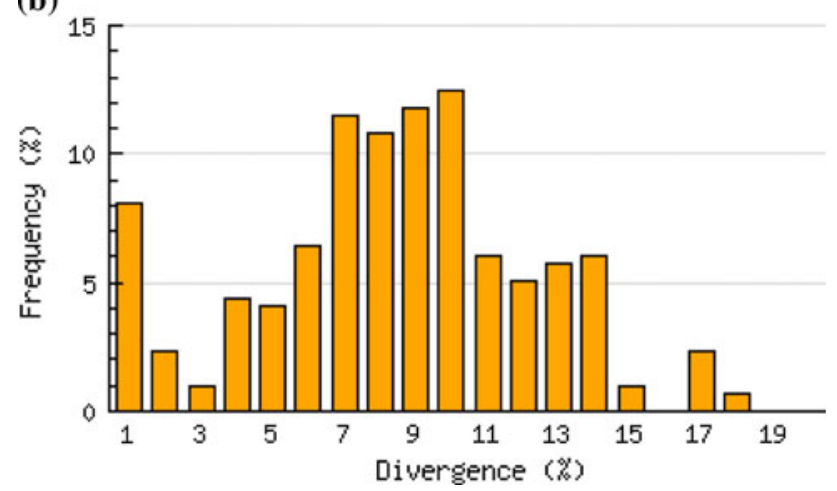

Fig. 1 Histograms showing the distribution of a average intraspecific distances and b the average nearest neighbor distance across 296 Scandinavian bird species
(93.6\%) had unique DNA barcodes with no overlap with other species and nearest neighbor distances ranging within the interval $0.94-17.05 \%$ (average $8.0 \%$ ) (see complete NJ-tree in electronic supplementary material). Bootstrap support for these monophyletic clusters averaged 99.84 (range 88-100). The Bayesian phylogenetic analysis gave virtually identical results (data not shown). Of these 277 species, 12 species had a distance to a sister species that fell below the threshold suggested by Hebert et al. (2004), which amounted to $2.4 \%$ in our study (average nearest neighbour distance for the 12 species $1.42 \%$, range 0.94 $1.74 \%$ ). Nevertheless, these 12 species had between 6 and 13 diagnostic base substitutions compared to their nearest neighbors. Three species pairs (Cygnus columbianus and C. cygnus, Gavia adamsii and G. immer, and Stercorarius pomarinus and S. skua) displayed high degrees of sequence similarity (99.38, 99.22, and 99.70\%, respectively); however, this observation should be treated with caution since one species in each of these pairs was only represented by one individual (see "Discussion"). Thirteen species (4.4\%) in five clusters had overlapping barcodes with one or more closely related species (Table 1), with sequence similarity ranging from 99.86 to $100 \%$.

Four species showed relatively high $(>2 \%)$ intraspecific sequence variation (Table 2). This is illustrated for Phoenicurus phoenicurus in Fig. 2 and for Lanius collurio in Fig. 3. For the two species with the highest intraspecific divergence (Phoenicurus phoenicurus and Periparus ater), we used the XL-PCR procedure and found support for a mitochondrial origin of the divergent haplotypes.

\section{Scandinavian versus North American species}

The sample contained 78 species breeding both in Scandinavia and North America. The average intraspecific between-continent distance was $0.85 \%$ (range $0-4.86 \%$ ) for these species (Table 3). Nineteen species (24\%) showed divergent genetic clusters in the two regions, with an average between-continent distance of $2.53 \%$ (range $0.45-4.86 \%$ ). For another three species (Lagopus lagopus, Fulmarus glacialis, Corvus corax), the Scandinavian birds clustered with some North American specimens in a clade that was clearly separable from a second North American clade. The remaining 56 species (72\%) showed little or no divergence related to continent, with an average betweencontinent distance of $0.25 \%$ (Table 3 ). Sixteen $(84 \%)$ of the species with trans-Atlantic splits were terrestrial or inland breeders, whereas more marine or aquatic species were represented among the 59 species with no distinct trans-Atlantic clustering (Table 3).

Three of the trans-Atlantic species were paraphyletic, that is, one cluster was more similar to a sister species than to the other intraspecific cluster. COI barcodes of North 
Table 1 Scandinavian species with overlapping barcode clusters

\begin{tabular}{|c|c|c|c|c|c|}
\hline Cluster & Order & Common name & Scientific name & $n$ & Similarity $(\%)$ \\
\hline \multirow[t]{3}{*}{1} & \multirow[t]{3}{*}{ Anseriformes } & Pink-footed Goose & Anser brachyrhynchus & 1 & \multirow[t]{3}{*}{99.84} \\
\hline & & Lesser white-fronted Goose & Anser erythropus & 1 & \\
\hline & & Bean Goose & Anser fabalis & 2 & \\
\hline \multirow[t]{2}{*}{2} & \multirow[t]{2}{*}{ Anseriformes } & Common Eider & Somateria mollissima & 4 & \multirow[t]{2}{*}{100} \\
\hline & & King Eider & Somateria spectabilis & 1 & \\
\hline \multirow[t]{4}{*}{3} & \multirow[t]{4}{*}{ Charadriiformes } & Herring Gull & Larus argentatus & 2 & \multirow[t]{4}{*}{99.86} \\
\hline & & Lesser black-backed Gull & Larus fuscus & 4 & \\
\hline & & Glaucous Gull & Larus hyperboreus & 2 & \\
\hline & & Greater black-backed Gull & Larus marinus & 4 & \\
\hline \multirow[t]{2}{*}{4} & \multirow[t]{2}{*}{ Passeriformes } & Common Redpoll & Carduelis flammea & 6 & \multirow[t]{2}{*}{100} \\
\hline & & Hoary Redpoll & Carduelis hornemanni & 5 & \\
\hline \multirow[t]{2}{*}{5} & \multirow[t]{2}{*}{ Passeriformes } & Common Crossbill & Loxia curvirostra & 6 & \multirow[t]{2}{*}{100} \\
\hline & & Parrot Crossbill & Loxia pytyopsittacus & 6 & \\
\hline
\end{tabular}

Table 2 Scandinavian species with large $(>2 \%)$ within-species variation

\begin{tabular}{llll}
\hline Common name & Scientific name & $\begin{array}{l}\text { Max. intraspecific } \\
\text { distance }(\%)\end{array}$ & $n$ \\
\hline Common Cuckoo & Cuculus canorus & 2.87 & 4 \\
Red-backed Shrike & Lanius collurio & 2.76 & 4 \\
Coal Tit & Periparus ater & 4.47 & 5 \\
Common Redstart & Phoenicurus phoenicurus & 5.08 & 7 \\
\hline
\end{tabular}

American Northern Shrikes Lanius excubitor were more closely related to the North American Loggerhead Shrike (Lanius ludovicianus) than to the Scandinavian Northern Shrikes (Fig. 3). Similarly, North American Sandwich Terns Thalasseus sandvicensis appeared more closely related to North American Elegant Terns (Thalasseus elegans) than to their Scandinavian counterparts (Fig. 4). North American Mew Gulls Larus canus grouped together within the shallow multispecies cluster of white-headed Larus gulls, while Scandinavian L. canus clustered outside the entire group with relatively good bootstrap support (Fig. 5). A mitochondrial origin of the Scandinavian sequences was supported by XL-PCR for Lanius excubitor and Larus canus, but not tested in Thalasseus sandvicensis due to technical problems.

\section{Discussion}

Cytochrome $c$ oxidase subunit I barcodes gave high species resolution of Scandinavian birds, with $94 \%$ of currently recognized species displaying unique barcodes. Five genetic clusters consisted of two or more congeneric species that could not be separated using the COI gene. The comparison of bird species breeding both in Scandinavia and North America revealed 19 species with well-defined haplotype groups confined to each continent, some of which had an inter-continental degree of divergence commonly seen at the between-species level. Our results thus contribute to the growing library of DNA barcodes of bird species of the world, and flag particular species and species groups in need of taxonomic reassessments.

The high resolution of COI in species identification among Scandinavian birds (94\%) is similar to that found in other studies of COI performance in well-known vertebrate groups, e.g., North American birds (94\%; Kerr et al. 2007), Australian fishes (100\%; Ward et al. 2005) and Neotropical bats (93\%; Clare et al. 2007), and contrasts with lower identification rates of $\mathrm{COI}$ in some invertebrate groups (e.g., Elias et al. 2007; Meier et al. 2006; Meyer and Paulay 2005). Obviously, the success of DNA barcoding as a species identification tool can only be evaluated in groups for which robust species taxonomy exists already. This is definitely the case for vertebrates, but less so for many invertebrate groups. In any case, resolution of more than $90 \%$ of all species is quite an impressive performance by a single genetic marker, and provides a cost-effective tool for screening of biodiversity (Hebert and Gregory 2005; Stoeckle and Hebert 2008). Resolution was higher when using uniqueness of $\mathrm{NJ}$-clusters (i.e., monophyly) as a species delimitation criterion (94\%) rather than the threshold genetic distance (89\%) proposed by Hebert et al. (2004). This is consistent with the results of two recent papers on DNA barcoding in closely related bird species (Aliabadian et al. 2009; Tavares and Baker 2008).

We found five species pairs or groups that could not be distinguished by DNA barcoding. In all five cases, the species or species groups in question were closely related congeners. There are two mutually non-exclusive hypotheses to explain a lack of COI haplotype divergence 


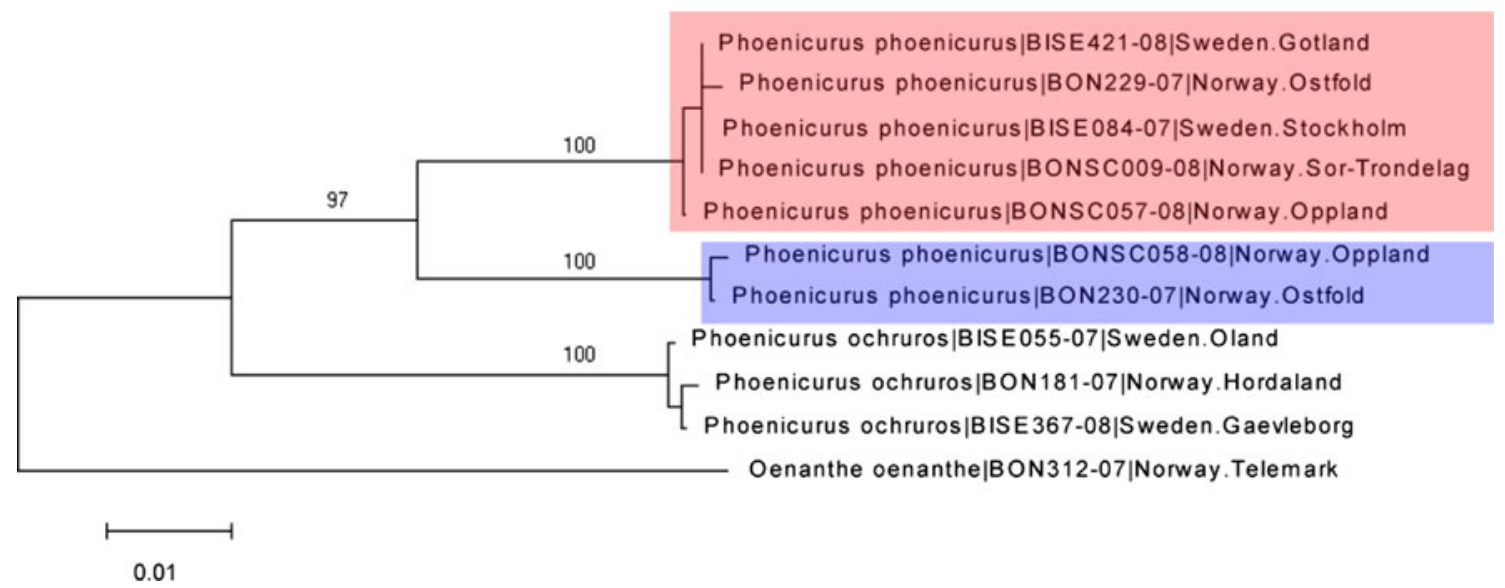

Fig. 2 Neighbor-joining tree (based on the Kimura 2 parameter) illustrating intraspecific distances in two congeneric passerine species, Phoenicurus phoenicurus and P. ochruros, with Oenanthe oenanthe as outgroup. The two divergent $P$. phoenicurus haplotypes are highlighted with colors/shading. For each individual, the scientific name is followed by the BOLD process ID number and the sampling locality
Fig. 3 Neighbor-joining tree (based on the Kimura 2 parameter) for three Lanius species, with Corvus cornix as outgroup. The tree illustrates the paraphyletic relationship between Lanius excubitor from North America (upper/blue box) and Scandinavia (lower/red box). For each individual, the scientific name is followed by the BOLD process ID number and the sampling locality

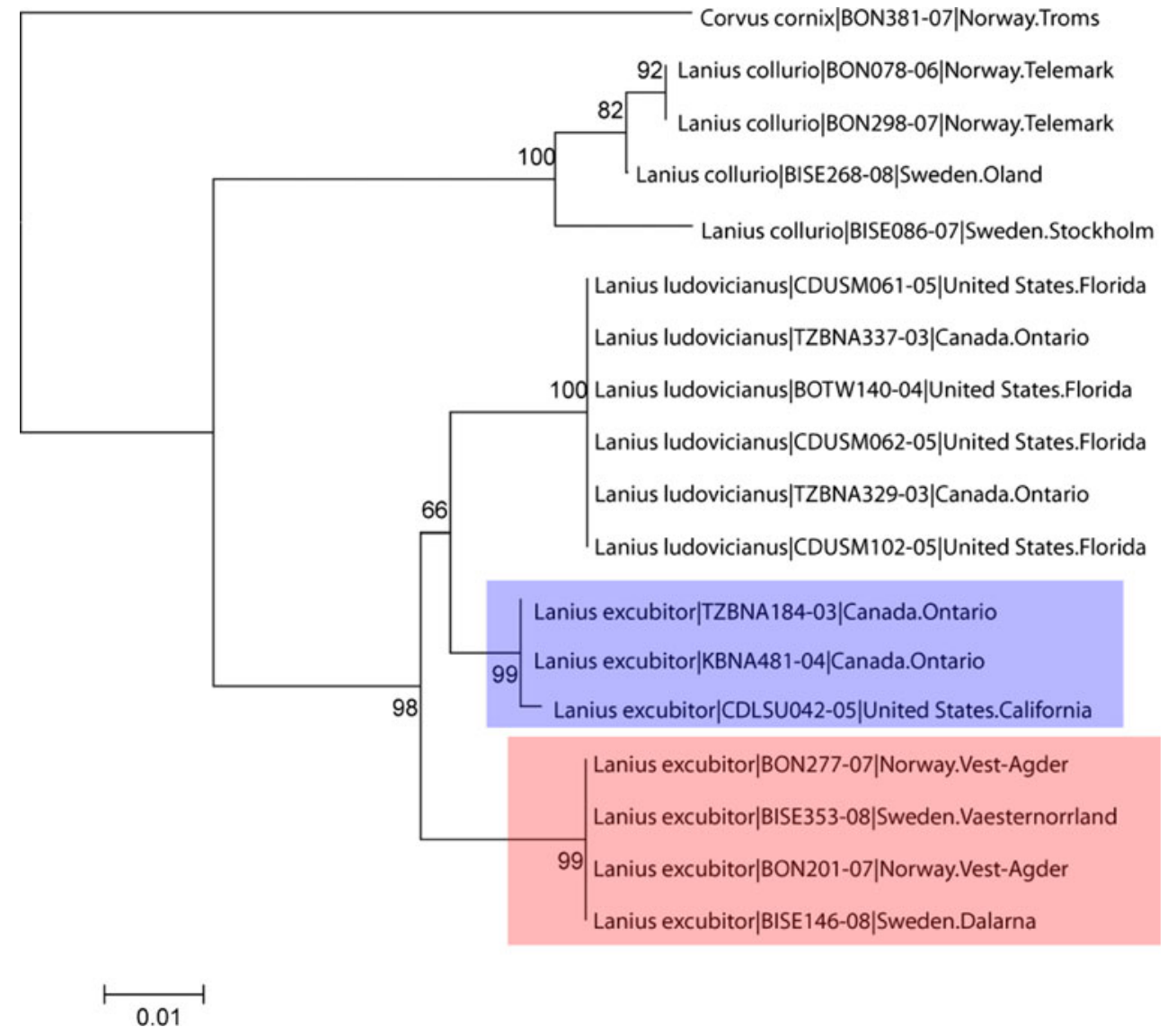

biased with respect to sex and species, one would expect to find two haplotype clusters, both consisting of a mix of both species. However, there could also be a directional bias in mtDNA transfer, which has been suggested for Stercoraria skua and S. pomarinus (Andersson 1999). All five groups of species with overlapping barcodes in this 
Table 3 Summary statistics for 78 species breeding both in Scandinavia and North America

\begin{tabular}{|c|c|c|c|c|c|c|c|c|}
\hline Scientific name & $\begin{array}{l}\text { Between } \\
\text { continents } \\
\text { K2P }\end{array}$ & $\begin{array}{l}\text { Intercontinental } \\
\text { clusters? }\end{array}$ & $\begin{array}{l}\text { Bootstrap } \\
\text { support }\end{array}$ & $\begin{array}{l}\text { Breeding } \\
\text { habitat }\end{array}$ & $\begin{array}{l}\text { Breeding } \\
\text { distribution }\end{array}$ & $\begin{array}{l}n \\
\text { (S/NA) }\end{array}$ & $\begin{array}{l}\text { Number of } \\
\text { diagnostic } \\
\text { positions }^{c}\end{array}$ & $\begin{array}{l}\text { Subspecies } \\
\text { (S/NA) }\end{array}$ \\
\hline Falco rusticolus & 0.00 & No & 98 & I & Continuous & $4 / 2$ & & \\
\hline Gavia stellata & 0.00 & No & 99 & I & Continuous & $4 / 2$ & & \\
\hline Larus marinus & 0.00 & No & Not $\mathrm{mp}$ & M & Discontinuous & $4 / 3$ & & \\
\hline Phalaropus fulicarius & 0.00 & No & 99 & I & Continuous & $3 / 2$ & & \\
\hline Podiceps auritus & 0.00 & No & 99 & I & Continuous & $4 / 1$ & & \\
\hline Somateria spectabilis & 0.00 & No & $97^{\mathrm{b}}$ & M & Continuous & $1 / 2$ & & \\
\hline Stercorarius pomarinus & 0.00 & No & 99 & M & Continuous & $1 / 5$ & & \\
\hline Streptopelia decaocto & 0.00 & No & 99 & I & Introduced & $2 / 2$ & & \\
\hline Branta bernicla & 0.02 & No & 98 & M & Continuous & $1 / 9$ & & \\
\hline Phalaropus lobatus & 0.02 & No & 99 & I & Continuous & $3 / 7$ & & \\
\hline Aquila chrysaetos & 0.04 & No & 99 & I & Discontinuous & $4 / 2$ & & \\
\hline Asio flammeus & 0.04 & No & 99 & I & Continuous & $4 / 5$ & & \\
\hline Cygnus olor & 0.04 & No & 99 & $\mathrm{I} / \mathrm{M}$ & Introduced & $4 / 2$ & & \\
\hline Melanitta fusca & 0.04 & No & 99 & $\mathrm{I} / \mathrm{M}$ & Discontinuous & $2 / 5$ & & \\
\hline Morus bassanus & 0.04 & No & 99 & M & Discontinuous & $4 / 4$ & & \\
\hline Passer montanus & 0.04 & No & 99 & I & Introduced & $4 / 2$ & & \\
\hline Somateria mollissima & 0.05 & No & $97^{\mathrm{b}}$ & M & Continuous & $4 / 10$ & & \\
\hline Anas acuta & 0.06 & No & 99 & I & Continuous & $3 / 7$ & & \\
\hline Branta canadensis & 0.06 & No & 46 & $\mathrm{I} / \mathrm{M}$ & Introduced & $4 / 122$ & & \\
\hline Columba livia & 0.06 & No & 99 & I & Discontinuous & $3 / 2$ & & \\
\hline Aythya marila & 0.07 & No & 99 & $\mathrm{I} / \mathrm{M}$ & Continuous & $3 / 10$ & & \\
\hline Clangula hyemalis & 0.07 & No & 99 & $\mathrm{I} / \mathrm{M}$ & Continuous & $3 / 9$ & & \\
\hline Branta leucopsis & 0.09 & No & 97 & M & Discontinuous & $4 / 1$ & & \\
\hline Cepphus grylle & 0.09 & No & 98 & M & Continuous & $5 / 2$ & & \\
\hline Riparia riparia & 0.09 & No & 99 & I & Discontinuous & $4 / 2$ & & \\
\hline Carduelis flammea & 0.11 & No & 90 & I & Continuous & $6 / 2$ & & \\
\hline Hydroprogne caspia & 0.12 & No & 99 & M & Discontinuous & $3 / 3$ & & \\
\hline Mergus serrator & 0.13 & No & 98 & $\mathrm{I} / \mathrm{M}$ & Continuous & $4 / 6$ & & \\
\hline Passer domesticus & 0.13 & No & 99 & I & Introduced & $4 / 4$ & & \\
\hline Alca torda & 0.14 & No & 99 & M & Discontinuous & $4 / 6$ & & \\
\hline Anas strepera & 0.14 & No & 88 & I & Discontinuous & $2 / 6$ & & \\
\hline Arenaria interpres & 0.16 & No & 99 & $\mathrm{I} / \mathrm{M}$ & Continuous & $4 / 3$ & & \\
\hline Falco peregrinus & 0.16 & No & 46 & I & Continuous & $4 / 3$ & & \\
\hline Stercorarius longicaudus & 0.17 & No & 99 & M & Continuous & $2 / 4$ & & \\
\hline Bubo scandiacus & 0.21 & No & 99 & I & Continuous & $4 / 4$ & & \\
\hline Anas clypeata & 0.22 & No & 99 & I & Continuous & $3 / 7$ & & \\
\hline Alle alle & 0.23 & No & 99 & M & Discontinuous & $4 / 3$ & & \\
\hline Oceanodroma leucorhoa & 0.23 & No & 99 & M & Discontinuous & $2 / 3$ & & \\
\hline Fratercula arctica & 0.25 & No & 99 & M & Discontinuous & $4 / 5$ & & \\
\hline Calidris alba & 0.26 & No & 99 & $\mathrm{I} / \mathrm{M}$ & Discontinuous & $2 / 3$ & & \\
\hline Sterna hirundo & 0.26 & No & 99 & $\mathrm{I} / \mathrm{M}$ & Discontinuous & $4 / 2$ & & \\
\hline Bucephala clangula & 0.30 & No & 96 & I & Continuous & $1 / 6$ & & \\
\hline Rissa tridactyla & 0.32 & No & 99 & M & Discontinuous & $2 / 7$ & & \\
\hline Oenanthe oenanthe & 0.34 & No & 99 & I & Continuous & $6 / 1$ & & \\
\hline Buteo lagopus & 0.39 & No & 99 & I & Continuous & $4 / 2$ & & \\
\hline Anas platyrhynchos & 0.46 & No & 95 & $\mathrm{I} / \mathrm{M}$ & Continuous & $4 / 8$ & & \\
\hline
\end{tabular}


Table 3 continued

\begin{tabular}{|c|c|c|c|c|c|c|c|c|}
\hline Scientific name & $\begin{array}{l}\text { Between } \\
\text { continents } \\
\text { K2P }\end{array}$ & $\begin{array}{l}\text { Intercontinental } \\
\text { clusters? }\end{array}$ & $\begin{array}{l}\text { Bootstrap } \\
\text { support }\end{array}$ & $\begin{array}{l}\text { Breeding } \\
\text { habitat }\end{array}$ & $\begin{array}{l}\text { Breeding } \\
\text { distribution }\end{array}$ & $\begin{array}{l}n \\
\text { (S/NA) }\end{array}$ & $\begin{array}{l}\text { Number of } \\
\text { diagnostic } \\
\text { positions }^{c}\end{array}$ & $\begin{array}{l}\text { Subspecies } \\
\text { (S/NA) }\end{array}$ \\
\hline Sturnus vulgaris & 0.55 & No & 99 & I & Introduced & $4 / 7$ & & \\
\hline Uria lomvia & 0.58 & No & 70 & M & Continuous & $3 / 3$ & & \\
\hline Podiceps grisegena & 0.63 & No & 99 & I & Discontinuous & $2 / 3$ & & \\
\hline Uria aalge & 0.65 & No & 89 & M & Discontinuous & $4 / 2$ & & \\
\hline Calcarius lapponicus & 0.70 & No & 99 & I & Continuous & $4 / 3$ & & \\
\hline Mergus merganser & 0.73 & No & 99 & $\mathrm{I} / \mathrm{M}$ & Discontinuous & $3 / 9$ & & \\
\hline Lagopus muta & 1.04 & No & 98 & I & Continuous & $3 / 18$ & & \\
\hline Calidris alpina & 1.10 & No & 99 & $\mathrm{I} / \mathrm{M}$ & Continuous & $4 / 3$ & & \\
\hline Loxia curvirostra & 1.15 & No & 82 & I & Discontinuous & $6 / 3$ & & \\
\hline Loxia leucoptera & 1.29 & No & 98 & I & Continuous & $2 / 2$ & & \\
\hline Lagopus lagopus & 1.03 & $\mathrm{No}^{\mathrm{a}}$ & $95 / 94$ & I & Continuous & $4 / 5$ & & $\begin{array}{l}\text { lagopus (variegata)/ } \\
\text { six NA }\end{array}$ \\
\hline Fulmarus glacialis & 1.18 & $\mathrm{No}^{\mathrm{a}}$ & 99 & M & Discontinuous & $4 / 3$ & & glacialis/rodgersii \\
\hline Corvus corax & 1.89 & $\mathrm{No}^{\mathrm{a}}$ & $95 / 98$ & I & Continuous & $4 / 5$ & & $\begin{array}{l}\text { corax/principalis, } \\
\text { sinuatus }\end{array}$ \\
\hline Melanitta nigra & 0.45 & Yes & $60 / 63$ & I & Discontinuous & $3 / 7$ & 1 & nigralamericana \\
\hline Eremophila alpestris & 0.52 & Yes & $67 / 66$ & I & Discontinuous & $2 / 2$ & 2 & Numerous \\
\hline Polysticta stelleri & 1.12 & Yes & -169 & M & Continuous & $1 / 2$ & 5 & None \\
\hline Asio otus & 1.13 & Yes & $85 / 85$ & I & Discontinuous & $4 / 4$ & 6 & otus/tuftsi (wilsonianus) \\
\hline Circus cyaneus & 1.36 & Yes & $66 / 86$ & I & Discontinuous & $4 / 4$ & 7 & cyaneus/hudsonius \\
\hline Hirundo rustica & 1.68 & Yes & $93 / 93$ & I & Discontinuous & $4 / 5$ & 9 & rusticalerythrogaster \\
\hline Larus canus & 1.91 & Yes & $64 / 86$ & M & Continuous & $4 / 4$ & 9 & canus/brachyrhynchus \\
\hline Falco columbarius & 2.28 & Yes & $94 / 94$ & I & Continuous & $4 / 4$ & 13 & aesalon/three NA \\
\hline Pandion haliaetus & 2.28 & Yes & $87 / 93$ & I & Discontinuous & $5 / 5$ & 12 & haliaetus/carolinensis \\
\hline Lanius excubitor & 2.51 & Yes & $89 / 89$ & I & Discontinuous & $4 / 3$ & 21 & $\begin{array}{l}\text { excubitor/borealis, } \\
\text { invictus }\end{array}$ \\
\hline Accipiter gentilis & 2.60 & Yes & $87 / 88$ & I & Discontinuous & $4 / 7$ & 14 & gentilis/atricapillus \\
\hline Gallinula chloropus & 3.24 & Yes & $97 / 99$ & I & Discontinuous & $3 / 5$ & 18 & chloropus/cachinnans \\
\hline Strix nebulosa & 3.31 & Yes & $93 / 95$ & I & Discontinuous & $4 / 4$ & 19 & lapponica/nebulosa \\
\hline Numenius phaeopus & 3.62 & Yes & 99/- & I & Discontinuous & $2 / 1$ & 18 & phaeopus/hudsonicus \\
\hline Aegolius funereus & 3.69 & Yes & $72 / 99$ & I & Discontinuous & $4 / 2$ & 19 & funereus/richardsoni \\
\hline Tyto alba & 3.73 & Yes & $99 / 99$ & I & Discontinuous & $2 / 3$ & 31 & $\begin{array}{l}\text { alba }(\text { guttata }) / \\
\text { pratincola }\end{array}$ \\
\hline Thalasseus sandvicensis & 3.95 & Yes & $99 / 99$ & M & Discontinuous & $2 / 8$ & 20 & $\begin{array}{l}\text { sandvicensis/ } \\
\text { acuflavidus }\end{array}$ \\
\hline Pinicola enucleator & 3.96 & Yes & $99 / 98$ & I & Continuous & $3 / 2$ & 22 & eunucleator/seven NA \\
\hline Troglodytes troglodytes & 4.86 & Yes & $99 / 95 / 73$ & I & Continuous & $4 / 7$ & 14 & troglodytes/numerous NA \\
\hline
\end{tabular}

Not $m p$ Not monophyletic, $I$ inland breeder, $M$ marine breeder, $S$ Scandinavia, NA North America

a Scandinavian birds cluster in one of two North American groups

b Overlapping barcode clusters

c Number of diagnostic base substitutions between the Scandinavian and the North American group(s)

study are known to hybridize occasionally today (McCarthy 2006). However, the specimens included in this study were selected for showing clear species identity based on morphology, hence current hybridization seems unlikely to explain the overlapping barcodes in most cases. Three of the five species groups were also identified as having overlapping barcodes in the previous study of North American birds (Somateria mollissima/spectabilis, Larus 
Fig. 4 Neighbor-joining tree (based on the Kimura 2 parameter) for three Thalasseus species, with Sterna hirundo as outgroup. The tree illustrates the paraphyletic relationship between Thalasseus sandvicensis from North America (lower/blue box) and Scandinavia (upper/red box). For each individual, the scientific name is followed by the BOLD process ID number and the sampling locality

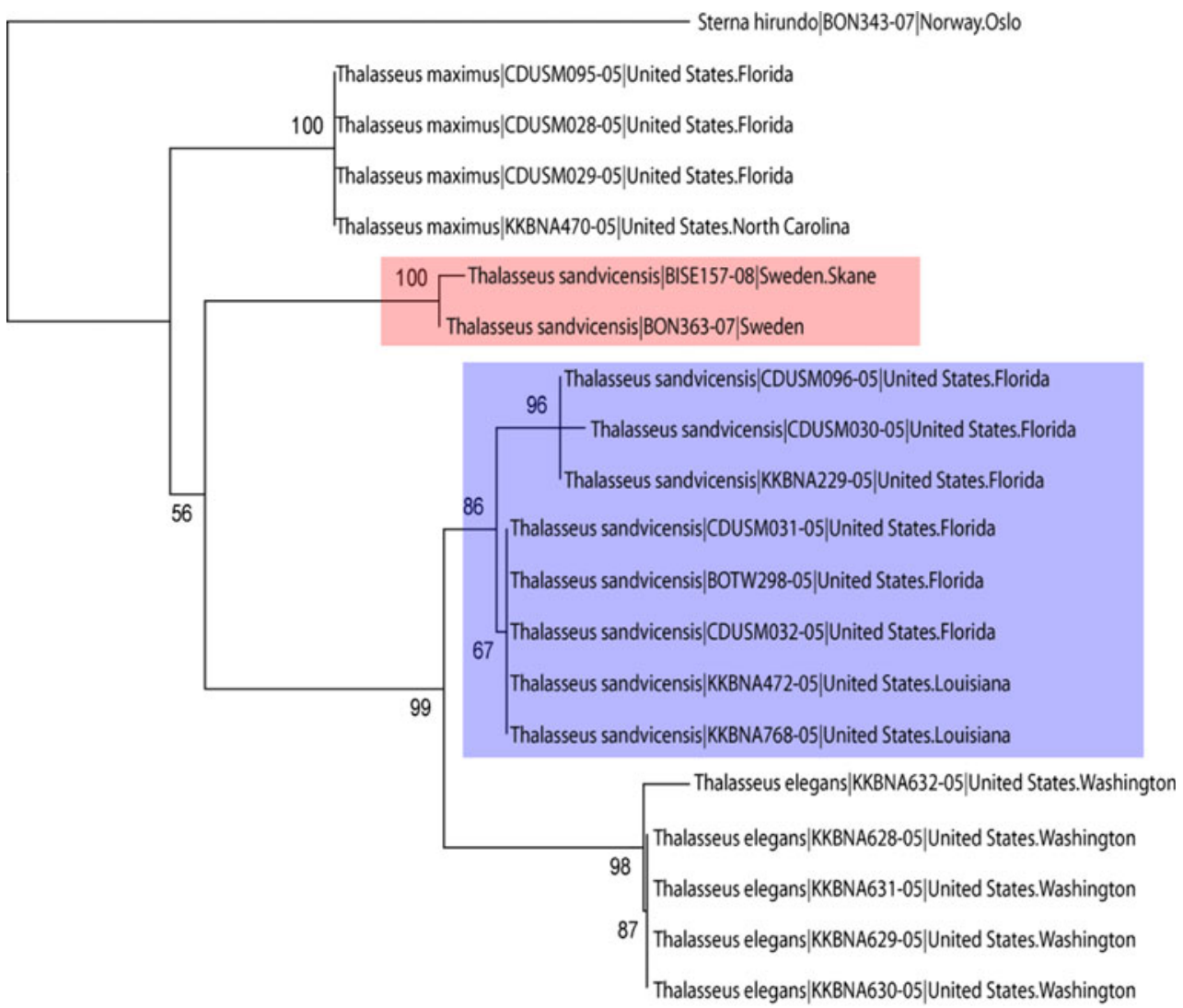

0.01 spp., and Carduelis flammea/hornemanni; Kerr et al. 2007). In the Larus case, our study adds L. marinus to the group of large white-headed gulls with overlapping barcodes. For the Somateria eiders and Larus gulls there is generally little doubt that the taxa in question behave as good biological species with distinct gene pools being reproductively isolated, even in sympatry. For the Carduelis flammeal hornemanni complex, the taxonomy has long been debated (Knox 1988; Marthinsen et al. 2008; Molau 1985). A recent study of mtDNA (control region) and nuclear (microsatellite) markers revealed no genetic differentiation within this species complex (Marthinsen et al. 2008). The possibility of one common gene pool, displaying distinct clinal morphological variation, cannot yet be ruled out (Marthinsen et al. 2008). The two crossbills, Loxia curvirostra and L. pytyopsittacus, were found to be morphologically distinct and to mate assortatively with respect to bill morphology, but they were not genetically distinct in either mtDNA or microsatellites (Summers et al. 2007). The Loxia species complex may be an example of recent ecological speciation caused by adaptation of beak size to different seed types (Benkman 2003; Smith and Benkman 2007).
Three species pairs (Cygnus columbianus and C. cygnus, Gavia adamsii and G. immer, and Stercorarius pomarinus and $S$. skua) showed non-overlapping, but very similar, barcodes. In each of these species pairs, one species was represented by a single specimen, which precludes any conclusion about consistent differences based on the Scandinavian samples alone. However, when pooling these specimens with the published North American ones (Kerr et al. 2007), well-defined monophyletic groups were observed in all six species, albeit with a very low degree of differentiation (data not shown). These and several of the species with overlapping barcodes may be young species, in which morphological divergences have established faster than neutral genetic divergences (Peters et al. 2005).

In contrast to interspecifically similar or overlapping barcodes, we also identified some Scandinavian species with large intraspecific sequence divergence, typically represented by two distinct haplotype lineages (Table 2). The magnitude of intraspecific divergence in COI exceeds typical species-level differences, particularly in Periparus ater and Phoenicurus phoenicurus, yet there is no indication that this large sequence variation represents cryptic species. There is no known morphological differentiation 
Fig. 5 Neighbor-joining tree (based on the Kimura 2 parameter) for ten Larus species, with Rissa tridactyla as outgroup. The tree illustrates the paraphyletic relationship between Larus canus from North America (lower/blue box) and Scandinavia (upper/red box). For each individual, the scientific name is followed by the BOLD process ID number and the sampling locality

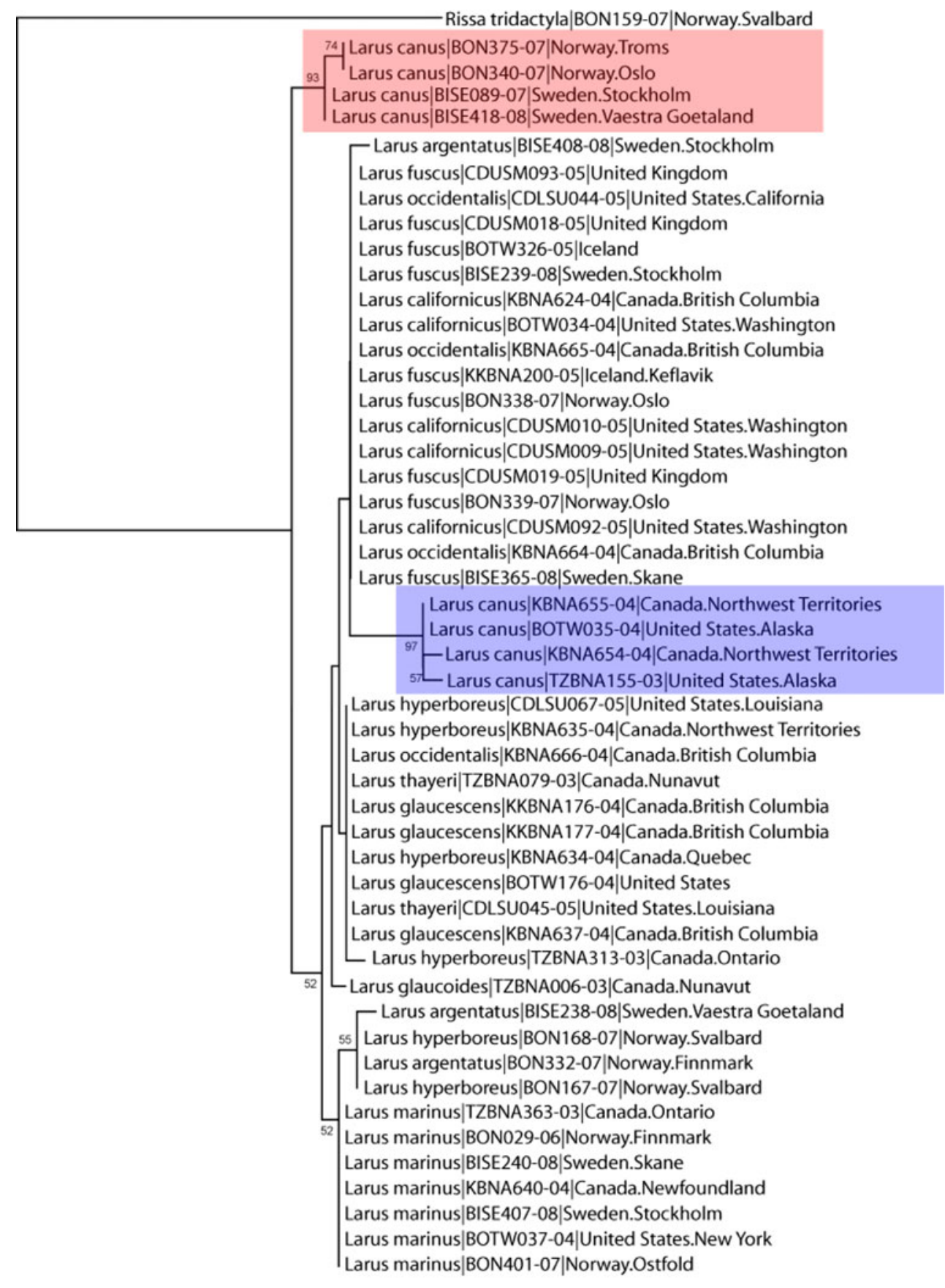

between these haplotype groups, and in the species with largest intraspecific distance, Phoenicurus phoenicurus, we have direct evidence for interbreeding of the haplotypes. Either these large intraspecific divergences are real and demand an evolutionary explanation, or they are analytical artifacts due to amplification of nuclear pseudogenes (Song et al. 2008). To test the latter alternative, we amplified a long fragment ( $>4,000 \mathrm{bp}$ ) using conserved mitochondrial markers (Sorenson et al. 1999), and used this as the basis for a second PCR with internal COI primers. This XL-PCR procedure supported a mitochondrial origin of the divergent haplotypes in these species. In addition, we amplified another mtDNA marker, the $16 \mathrm{~S}$ gene, for some specimens to see if they segregated similarly as for COI. This confirmed the segregation pattern for Periparus ater and Phoenicurus phoenicurus (A. Johnsen and J.T. Lifjeld, unpublished data). Furthermore, for all four species in Table 2, we have unpublished barcode results of specimens from other parts of the Palearctic, which adhere to the same pattern of two or more separate lineages within the species 
range (K.C.R. Kerr et al., unpublished data; A. Johnsen and J.T. Lifjeld, unpublished data). Hence, the most parsimonious explanation for these divergences is that the current populations consist of a mixture of separate lineages that once evolved in allopatry but at some point in time merged and have since survived as two separate clusters in sympatry. Only sequencing of more specimens from a wider geographical coverage of their ranges can elucidate the phylogeographical history of these lineages.

Our comparison of sequence divergence among 78 Holarctic species occurring both in Scandinavia and North America revealed 19 species with well-defined barcode clusters for each continent, with another three species (Lagopus lagopus, Fulmarus glacialis, Corvus corax) in which Scandinavian birds clustered with one of two North American groups. For one of the latter species, Corvus corax, a similar pattern was found using the mitochondrial control region (Omland et al. 2006). The remaining 56 species had low intraspecific divergence and no consistent intercontinental groupings. Six of these species have been introduced from Europe to North America (Streptopelia decaocto, Cygnus olor, Passer domesticus, Sturnus vulgaris, and Columba livia) or vice versa (Branta canadensis), hence their lack of genetic divergence is not surprising. More than half $(60 \%)$ the naturally occurring species with no divergence between the continents have a more or less continuous distribution from western Europe to eastern Siberia which continues on the other side of the Bering strait into Alaska and further into North America, while $70 \%$ of the remaining species with discontinuous distribution are marine breeders (see Table 3). In contrast, 14 of the 19 divergent species (74\%) show a discontinuous distribution with little geographic connection between populations on the two continents, and the majority (84\%) are inlandbreeding birds. The likelihood of gene flow between the continents therefore seems very low for many of these species. Previous studies, using other genetic markers, have found strong intercontinental genetic divergence in 11 of the 19 divergent species identified in the present study: Aegolius funereus (Koopman et al. 2005), Circus cyaneus (Wink and Sauer-Gürth 2004), Falco columbarius (Wink and Sauer-Gürth 2004), Hirundo rustica (Zink et al. 2006), Lanius excubitor (Gonzalez et al. 2008; Klassert et al. 2008), Larus canus (Zink et al. 1995), Numenius phaeopus (Zink et al. 1995), Pandion haliaetus (Wink et al. 2004), Thalasseus sandvicensis (Efe et al. 2009), Troglodytes troglodytes (Drovetski et al. 2004), and Tyto alba (Wink et al. 2008). For almost all the divergent species, different subspecies have been described on each continent (Clements 2007), and in many cases the divergence matches current subspecific taxonomy. It is an important but unresolved issue in avian taxonomy what merits subspecific or specific taxonomic status in each case. If more extensive sampling confirms these patterns of monophyly, it is a highly relevant issue for avian taxonomic authorities whether these subspecies should be lifted to the species rank. As argued by Zink (2004), a high proportion of current avian subspecies are not monophyletic units and should therefore not be assigned a taxonomic name or rank. An implication of this view, following a phylogenetic species concept, is that monophyletic groups should be assigned the rank of species. We would not make specific recommendations for taxonomy here, since our analyses in most cases reflect a restricted and geographically limited sampling within the species' ranges. However, we would like to comment more specifically on the three particular cases of transAtlantic splits that revealed evidence of paraphyletic groups.

First, North American Lanius excubitor (probably belonging to the subspecies borealis and invictus) formed a sister clade to L. ludovicianus, whereas European L. excubitor (subspecies excubitor) clustered outside this North American clade (Fig. 3). This pattern is supported by Gonzalez et al. (2008) and Klassert et al. (2008), who both analyzed the Lanius excubitor/meridionalis complex with the cytochrome $b$ gene, and found L. e. excubitor on the European side and L. e.invictus on the North American side to be paraphyletic. L. excubitor is widely distributed in the northern Holarctic, but does not occur in northeastern Siberia, making the geographic distance between Palearctic and Nearctic birds very long. Gene flow between these populations should therefore be negligible, and the relatively large sequence divergence $(2.5 \%)$ between them suggests that they have been separated for a long time. A mitochondrial origin of the Scandinavian sequences was supported by XL-PCR, hence the patterns found are unlikely to result from amplification of pseudogenes. Second, North American Thalasseus sandvicensis (subspecies acuflavidus), clustered together with another North American Thalasseus species, T. elegans, while the European T. sandvicensis (subspecies sandvicensis) formed a group outside this clade (Fig. 4). T. sandvicensis breeds on each side of the Atlantic Ocean and shows a 3.9\% sequence divergence between the continents. This combination of large sequence difference, geographic separation, and paraphyly suggests that these populations should be considered separate species (i.e., acuflavidis be given species rank), supporting the conclusions of a recent paper documenting similar divergences in both mitochondrial and nuclear markers between Spanish and American Thalasseus sandvicensis (Efe et al. 2009). Third, Scandinavian Larus canus (subspecies canus) formed a clade outside the large clade of white-headed Larus gulls to which North American L. canus (subspecies brachyrhynchus) belong (Fig. 5). A mitochondrial origin of the Scandinavian Larus canus sequences was supported by XL-PCR. Larus canus has a more or less continuous circumpolar distribution, but 
the Bering Strait may act as a barrier to gene flow, as suggested by Zink et al. (1995). Even if the overall divergence between the continents $(1.9 \%)$ was more moderate than for the previous two species, paraphyly in COI indicates that a taxonomic revision is needed. Other species that deserve more detailed study include Gallinula chloropus, Strix nebulosa, Numenius phaeopus, Tyto alba, and Pinicola enucleator, all of which have $>3 \%$ continental divergence.

Three North American species have recently been split from their Eurasian counterparts (Anas carolinensis from A. crecca, Gallinago delicata from G. gallinago, and Picoides dorsalis from P. tridactylus) (Clements 2007). The combined Scandinavian and North American barcoding projects provide support for two of these splits (A. carolinensis and A. crecca: nearest neighbor distance $3.56 \%$, and P. dorsalis and P. tridactylus: nearest neighbor distance $3.69 \%$ ), but not for the third one, since G. delicata cannot be separated from G. gallinago based on COI barcodes (nearest neighbor distance 0\%).

In conclusion, we have shown that DNA barcoding with COI has a high species resolution for Scandinavian birds. Our approach also identified several species with large intraspecific variation as well as some species groups with overlapping barcodes, which make them good candidates for further studies of phylogeography and speciation processes. In particular, our comparison of trans-Atlantic species identified several species with deep intercontinental divergences. Further phylogenetic work on these species, using other genetic markers as well as morphology, will reveal which of these highly divergent and geographically separated populations should be treated as belonging to the same species or sister species. We leave it to the taxonomic authorities to decide, but we are convinced that continued DNA barcoding of birds from various regions of the world will be of great help for avian taxonomists in the continuing process of delimiting species. Lastly, we found that the DNA barcoding approach greatly amplified the power of our regional studies by enabling easy merging of our independently obtained datasets with the established avian barcode library (http://www.barcodingbirds.org).

\section{Zusammenfassung}

DNA-barcoding skandinavischer Vögel zeigt

divergente Abstammungslinien bei transatlantischen Arten

Vögel sind eine taxonomisch gut beschriebene Tiergruppe, doch DNA-Barcoding, die molekulare Charakterisierung von Arten mittels eines standardisierten genetischen Markers, hat unerwartete Muster genetischer Divergenz bei nordamerikanischen Vögeln aufgezeigt. Wir haben eine umfassende COI (Cytochrom-c-Oxidase-Untereinheit I) Barcode-Erfassung von 296 skandinavischen Vogelarten durchgeführt und genetische Divergenzen zwischen 78 transatlantischen Arten verglichen, deren Brutgebiete sowohl Skandinavien als auch Nordamerika einschließen. Vierundneunzig Prozent der skandinavischen Arten zeigten einzigartige Barcode-Cluster; die verbleibenden sechs Prozent hatten überlappende Barcodes mit einer oder mehreren Arten der gleichen Gattung, was „incomplete lineage sorting" oder einen einzigen Genpool widerspiegeln könnte. Vier Arten zeigten große innerartliche Divergenzen innerhalb Skandinaviens, trotz fehlender offensichtlicher morphologischer Differenzierung oder Anzeichen reproduktiver Isolation. Diese Fälle könnten Beimischung zuvor isolierter Linien widerspiegeln und daher umfassendere phylogeographische Analysen rechtfertigen. Neunzehn (24\%) von 78 transatlantischen Arten zeigten divergente genetische Cluster, die mit regionalen Unterarten übereinstimmen. Drei dieser transatlantischen Divergenzen waren paraphyletisch. Unsere Studie zeigt die Effektivität von COI-Barcodes für die Identifizierung skandinavischer Vögel und hebt Taxa für eine taxonomische Nachprüfung hervor. Der standardisierte DNA-Barcoding Ansatz verstärkte die Power unserer regionalen Studien, indem er es ermöglichte, unabhängig gewonnene Datensätze mit der etablierten Vogel-Barcode-Bibliothek zu fusionieren.

Acknowledgments We would like to thank the following people and institutions for providing samples: Roar Solheim (Agder Museum of Natural History), Ingvar Byrkjedal (Bergen Museum), Per Ole Syvertsen (Helgeland Museum), Robert Barrett (Troms $\varnothing$ University Museum), Göran Sjöberg (Ajtte, Swedish Mountain and Sami Museum), and Göran Nilson (Göteborg Natural History Museum). We are also grateful to numerous bird ringers who have contributed blood samples to the NHM DNA/tissue collection, and especially the bird observatories at Jomfruland, Lista, and Utsira in Norway. Credits are due to Gunnhild Marthinsen, Liv Wennerberg, Jarl Andreas Anmarkrud and Silje Hogner for performing parts of the DNA sequencing. This study was funded by the Natural History Museum, Oslo, the Swedish Museum of Natural History, the Swedish Research Council (grant no. 621-2007-5280), and the Swedish Research Council for Environment, Agricultural Sciences and Spatial Planning (grant no. 2006-714).

Open Access This article is distributed under the terms of the Creative Commons Attribution Noncommercial License which permits any noncommercial use, distribution, and reproduction in any medium, provided the original author(s) and source are credited.

\section{References}

Aliabadian M, Kaboli M, Nijman V, Vences M (2009) Molecular identification of birds: performance of distance-based DNA barcoding in three genes to delimit parapatric species. PLoS ONE 4:e4119 
Andersson M (1999) Hybridization and skua phylogeny. Proc R Soc Lond B 266:1579-1585

Benkman CW (2003) Divergent selection drives the adaptive radiation of crossbills. Evolution 57:1176-1181

Bensasson D, Zhang DX, Hartl DL, Hewitt GM (2001) Mitochondrial pseudogenes: evolution's misplaced witnesses. Trend Ecol Evol $16: 314-321$

Clare EL, Lim BK, Engstrom MD, Eger JL, Hebert PDN (2007) DNA barcoding of Neotropical bats: species identification and discovery within Guyana. Mol Ecol Notes 7:184-190

Clements JF (2007) The Clements checklist of birds of the world, 6th edn. Cornell University Press, Ithaca

del Hoyo J, Elliot A, Sargatal J, Christie D (1992-2008) Handbook of the birds of the world. Lynx, Barcelona

Dove CJ, Rotzel NC, Heacker M, Weigt LA (2008) Using DNA barcodes to identify bird species involved in birdstrikes. J Wildl Manage 72:1231-1236

Drovetski SV, Zink RM, Rohwer S, Fadeev IV, Nesterov EV, Karagodin I, Koblik EA, Red'kin YA (2004) Complex biogeographic history of a Holarctic passerine. Proc R Soc Lond B 271:545-551

Efe MA, Tavares ES, Baker AJ, Bonatto SL (2009) Multigene phylogeny and DNA barcoding indicate that the Sandwich tern complex (Thalasseus sandvicensis, Laridae, Sternini) comprises two species. Mol Phyl Evol 52:263-267

Elias M, Hill RI, Willmott KR, Dasmahapatra KK, Brower AVZ, Mallet J, Jiggins CD (2007) Limited performance of DNA barcoding in a diverse community of tropical butterflies. Proc $\mathrm{R}$ Soc B 274:2881-2889

Frezal L, Leblois R (2008) Four years of DNA barcoding: current advances and prospects. Infect Genet Evol 8:727-736

Gonzalez J, Wink M, Garcia-del-Rey E, Delgado Castro G (2008) Evidence from DNA nucleotide sequences and ISSR profiles indicates paraphyly in subspecies of the Southern Grey Shrike (Lanius meridionalis). J Ornithol 149:495-506

Hajibabaei M, Janzen DH, Burns JM, Hallwachs W, Hebert PDN (2006) DNA barcodes distinguish species of tropical Lepidoptera. Proc Natl Acad Sci USA 103:968-971

Hebert PDN, Gregory TR (2005) The promise of DNA barcoding for taxonomy. Syst Biol 54:852-859

Hebert PDN, Ratnasingham S, de Waard JR (2003) Barcoding animal life: cytochrome $\mathrm{c}$ oxidase subunit 1 divergences among closely related species. Proc R Soc Lond B 270:S96-S99

Hebert PDN, Stoeckle MY, Zemlak TS, Francis CM (2004) Identification of birds through DNA barcodes. PLoS Biol 2:1657-1663

Huelsenbeck JP, Ronquist F (2001) MRBAYES: Bayesian inference of phylogenetic trees. Bioinformatics 17:754-755

Kerr KCR, Stoeckle MY, Dove CJ, Weigt LA, Francis CM, Hebert PDN (2007) Comprehensive DNA barcode coverage of North American birds. Mol Ecol Notes 7:535-543

Klassert TE, Hernández MÁ, Campos F, Infante O, Almeida T, Suárez NM, Pestano J, Hernández M (2008) Mitochondrial DNA points to Lanius meridionalis as a polyphyletic species. Mol Phyl Evol 47:1227-1231

Knox AG (1988) The taxonomy of redpolls. Ardea 76:1-26

Koopman ME, McDonald DB, Hayward GD, Eldegard K, Sonerud GA, Sermach SG (2005) Genetic similarity among Eurasian subspecies of boreal owls Aegolius funereus. J Avian Biol 36:179-183

Lohman DJ, Prawiradilaga DM, Meier R (2008) Improved COI barcoding primers for Southeast Asian perching birds (Aves: Passeriformes). Mol Ecol Res 9999

Marthinsen G, Wennerberg L, Lifjeld JT (2008) Low support for separate species within the redpoll complex (Carduelis flammea- hornemanni-cabaret) from analyses of mtDNA and microsatellite markers. Mol Phyl Evol 47:1005-1017

McCarthy EM (2006) Handbook of avian hybrids of the world. Oxford University Press, New York

Meier R, Shiyang K, Vaidya G, Ng PKL (2006) DNA barcoding and taxonomy in diptera: a tale of high intraspecific variability and low identification success. Syst Biol 55:715-728

Meyer CP, Paulay G (2005) DNA barcoding: error rates based on comprehensive sampling. PLoS Biol 3:2229-2238

Molau U (1985) The redpoll complex in Sweden. Vår Fågelvärld 44:5-20

Moritz C, Cicero C (2004) DNA barcoding: promise and pitfalls. PLoS Biol 2:1529-1531

Neigel J, Domingo A, Stake J (2007) DNA barcoding as a tool for coral reef conservation. Coral Reefs 26:487-499

Omland KE, Baker JM, Peters JL (2006) Genetic signatures of intermediate divergence: population history of Old and New World Holarctic ravens (Corvus corax). Mol Ecol 15:795-808

Peters JL, McCracken KG, Zhuravlev YN, Lu Y, Wilson RE, Johnson KP, Omland KE (2005) Phylogenetics of wigeons and allies (Anatidae: Anas): the importance of sampling multiple loci and multiple individuals. Mol Phyl Evol 35:209-224

Posada D, Crandall KA (1998) MODELTEST: testing the model of DNA substitution. Bioinformatics 14:817-818

Ratnasingham S, Hebert PDN (2007) BOLD: The Barcode of Life Data System (http://www.barcodinglife.org). Mol Ecol Notes 7:355-364

Smith JW, Benkman CW (2007) A coevolutionary arms race causes ecological speciation in crossbills. Am Nat 169:455-465

Song H, Buhay JE, Whiting MF, Crandall KA (2008) Many species in one: DNA barcoding overestimates the number of species when nuclear mitochondrial pseudogenes are coamplified. Proc Natl Acad Sci USA 105:13486-13491

Sorenson MD, Quinn TW (1998) Numts: a challenge for avian systematics and population biology. Auk 115:214-221

Sorenson MD, Ast JC, Dimcheff DE, Yuri T, Mindell DP (1999) Primers for a PCR-based approach to mitochondrial genome sequencing in birds and other vertebrates. Mol Phyl Evol 12:105-114

Stoeckle MY, Hebert PDN (2008) Barcode of life. Sci Am 299:82-88

Summers RW, Dawson RJG, Phillips RE (2007) Assortative mating and patterns of inheritance indicate that the three crossbill taxa in Scotland are species. J Avian Biol 38:153-162

Tavares E, Baker A (2008) Single mitochondrial gene barcodes reliably identify sister-species in diverse clades of birds. BMC Evol Biol 8:81

Ward RD, Zemlak TS, Innes BH, Last PR, Hebert PDN (2005) DNA barcoding Australia's fish species. Philos Trans R Soc Lond B 360: $1847-1857$

Ward RD, Holmes BH, White WT, Last PR (2008a) DNA barcoding Australasian chondrichthyans: results and potential uses in conservation. Mar Freshw Res 59:57-71

Ward RD, Holmes BH, Yearsley GK (2008b) DNA barcoding reveals a likely second species of Asian sea bass (barramundi) (Lates calcarifer). J Fish Biol 72:458-463

Wink M, Sauer-Gürth H (2004) Phylogenetic relationships in diurnal raptors based on nucleotide sequences of mitochondrial and nuclear marker genes. In: Chancelor RD, Meyburg B-U (eds) Raptors worldwide. WWGBP, Berlin

Wink M, Sauer-Gürth H, Witt H-H (2004) Phylogenetic differentiation in the Osprey (Pandion haliaetus) inferred from nucleotide sequences of the mitochondrial cytochrome $b$ gene. In: Chancellor RD, Meyburg B-U (eds) Raptors worldwide. WWGBP, Berlin

Wink M, Heidrich P, Sauer-Gürth H, Elsayed A-A (2008) Molecular phylogeny and systematics of owls (Strigiformes). In: König C, Weick F (eds) Owls of the world. Black, London 
Wong EHK, Hanner RH (2008) DNA barcoding detects market substitution in North American seafood. Food Res Int 41:828837

Zink RM (2004) The role of subspecies in obscuring avian biological diversity and misleading conservation policy. Proc R Soc Lond B 271:561-564
Zink RM, Rohwer S, Andreev AV, Dittmann DL (1995) TransBeringia comparisons of mitochondrial DNA differentiation in birds. Condor 97:639-649

Zink RM, Pavlova A, Rohwer S, Drovetski SV (2006) Barn swallows before barns: population histories and intercontinental colonization. Proc R Soc Lond B 273:1245-1251 